\title{
The Effect of Save The Last Word For Me Method
}

\author{
Albert Efendi Pohan ${ }^{1}$; Devi Andriyani ${ }^{2}$ \\ English Education Department \\ University of Riau Kepulauan \\ guruindonesia31@gmail.com ${ }^{1}$; deviandriyani989@yahoo.com ${ }^{2}$
}

\begin{abstract}
The objective of the study is to find out the effect of using save the last word for me method toward students' writing skill for the eighth grade students' at SMPN 36 Batam in academic year 2016/2017. The kind of this study was quantitative research. The research design was experimental design. In this study focused on quasi experimental design. The population of this study was all students for the eighth grade at SMPN 36 Batam in Academic Year 2016/2017 consist of 270 students. The sampling technique was purposive sampling. Then, the total number of sample was 60 students that consisted of 30 students of class VIII.6 who were taught by using Save The Last Word For Me method and 30 students of class VIII.4 who were taught by using Think Pair Share method. The data was collected by test. The data was analyzed by using normality test, homogeneity test and hypothesis test. The result showed that the t-observed was 2.97 and the t-table was 2.002 . It means that t-observed was higher than $t$-table. Therefore, alternative hypothesis $\left(H_{a}\right)$ was accepted and null hypothesis $\left(H_{0}\right)$ was rejected. The research found that there was a significant effect of using Save The Last Word For Me method toward students' writing skill for the eighth grade students' at SMPN 36 Batam in academic year 2016/2017.
\end{abstract}

Keywords: writing skill, save the last word for me method, experimental research

\section{INTRODUCTION}

English is very important for communication both oral and written because it's function as an international language. Almost all countries agreed English mastery targetes to the general public such as government environments, employees, teacher, society, learner and especially for the students in junior high school. The mastery of English is needed to control with some main purposes such as have skill for communication in compete and for communication in conveying some purposes. In general, English consist of four skill such as skill in listening, speaking, reading and writing. It is related each other. The researcher in this research is focused in explaining writing.

According to Veit et al (2014:3) stated that writing is a complex process that various subskills from the basics of handwriting and spelling to the subtler nuances of tone and 
organization. The teacher must teaching writing to students which have other basic understanding in content, organization, vocabulary, language use and mechanics which writing is different from speech. It is important aspects that should be established in good writing. The students are needed to make a good writing begin with a good idea without an interesting idea, even the most skillful writing will result in a weak piece.

There were several problems faced by students in writing recount text that found by the researcher in writing recount text. First, the students did not have enough vocabulary and grammar so it made the students afraid in writing recount text. Second, the students did not understand how to express their ideas and opinions connected to the topic. Third, the students lacked of an interesting in writing recount text.

To increase the writing skill of the students, teachers need to develop a good method of writing. The teaching process will not give a good result if the procedures of teaching are not appropriate. Therefore, researcher assumed that this problem should be responded to improve the students in writing recount text by using Save The Last Word For Me method.

According to Patel and Jain (2008:125) said that writing skill is kind of linguistic behaviour; a picture is not. It presents the sounds of language through visual symbols. According to Irawati $(2013: 15)$ stated that five steps of the writing process, there are:

\section{Pre-writing}

Choose a topic, identify your audience and purpose, brainstorm ideas and organize information.

\section{Drafting}

Write your ideas in sentences and paragraphs. Follow your pre-writing plan to write a first draft of your composition.

\section{Revising}

Edit your writing. You make changes that will improve your writing.

\section{Proofreading}

In this stage, finish your editing by checking for errors in grammar, spelling, capitalization and punctuation. 


\section{Publishing}

The final stage is publishing when you decide how to present your writing to an audience. You may add pictures or read your work aloud.

According to Knoch (2009:105) stated that eight aspects of writing assessment, namely: accuracy, fluency, complexity, mechanics, cohesion, coherence, reader/writer interaction and content. According to Rasinski and Padak (2000) in Brunner (2011:85) said that Save The Last Word For Me method is designed to enhance student understanding of text material, as well as to foster group interaction and problem solving.

According to Rasinski and Padak (2000) in Brunner (2011:85) said that steps of Save The Last Word For Me method are:

1. Assign students to groups of three

2. Ask students to read all or part of the text silently

3. Using a piece of paper, instruct them to write a note areas of agreement/disagreement with the author and questions that occur to them while reading

4. Students discuss the text with the group. Each member of the group should select a comment or question from the notecards for the purpose of discussion

5. Ask other members of the group to react to the comment or question by sharing opinions or areas of agreement or disagreement

6. Ask the student who initially shared the question or comment to have the "last word" by summarizing the discussion or by offering his or her own opinion.

According to Rasinski and Padak (2000) in Brunner (2011:85) said that benefits of Save The Last Word For Me method as follows:

1. Easily implemented

2. Requires only moderate advance preparation from the teacher

3. A good activity for a classroom with a wide range of ability

4. Provides a framework for discussion of text

\section{METHODOLOGY}

The kind of this research was quantitative research. According to Sugiyono (2012:7) said that quantitative research is a research which analyze the data by using statistic. This research was used experimental research because the purpose of this research is to identify 
cause-effect between both of the variables, which Save The Last Word For Me Method (X), and Students' Writing Skill (Y).

Moreover, Sugiyono (2012:72) stated that experimental research is a research method that used to find influence a treatment to the other in controlled condition. The experimental design have two classes, namely: an experimental class and control class. This kind of experiment was quasi experimental design.

The instrument in this research was collected by giving test in writing recount text. The data of this research was the students' scores of pre-test and post-test to measure the students' skill in writing recount text. Furthermore, the researcher collected the students' writing with did assessment of writing was used to measure students ability of writing test. After the researcher collecting the data, it was analyzed by using the quantitative data that consist of normality test, homogeneity test and hypothesis test by using t-test.

\section{RESULTS}

\section{Testing Instrument}

\section{Normality test}

Normality test is tested by using chi quadrate formula as performed below:

$$
\mathrm{X}^{2}=\Sigma \frac{\left(\mathrm{f}_{0}-\mathrm{f}_{\mathrm{e}}\right)^{2}}{\mathrm{f}_{\mathrm{e}}}
$$

Where :

$$
\begin{array}{ll}
X^{2} & =\text { chi quadrate } \\
\mathrm{f}_{0} & =\text { observerd frequency } \\
\mathrm{f}_{\mathrm{e}} & =\text { expected frequency } \\
\text { If } X_{\text {count }}^{2} \geq X_{\text {table }}^{2} & =\text { the distributed data is not normal } \\
\text { If } X_{\text {count }}^{2} \leq X_{\text {table }}^{2} & =\text { the distributed data is normal }
\end{array}
$$

The result of the calculation, the data of pre-test in experimental class got $X_{\text {count }}^{2}(9.95) \leq X^{2}$ table $(11.070)$ and the data of post-test in experimental class got $X_{\text {count }}^{2}(9.25) \leq X^{2}$ table $(11.070)$. Then, the data of pre-test in control class got $X_{\text {count }}^{2}(8.0) \leq X_{\text {table }}^{2}(11.070)$ and the data of post-test in control class got $X_{\text {count }}^{2}(6.25) \leq X_{\text {table }}^{2}(11.070)$. Therefore, the research could be concluded that the data was normal distributed. 


\section{Homogeneity Test}

Homogeneity test is tested by using F-test formula as performed below:

$$
F=\frac{\text { Bigger variance }}{\text { Smaller variance }}
$$

The result of the calculation, $F_{\text {observed }}$ for students' pre-test writing skill (1.16) and post-test writing skill (1.73) was lower than $F_{\text {table }}(1.85)$. It means that both of the variances were homogenous.

\section{Hypothesis Test}

Hypothesis test is tested by using t-test formula as performed below:

$$
t=\frac{\bar{x}_{1}-\bar{x}_{2}}{\sqrt{\frac{s_{1}{ }^{2}}{n_{1}}+\frac{s_{2}{ }^{2}}{n_{2}}}}
$$

\section{Where:}

$$
\begin{aligned}
& \mathrm{t}=\mathrm{t} \text {-test } \\
& \bar{x}_{1}=\text { mean of pre-test and post-test in experimental class } \\
& \bar{x}_{2}=\text { mean of pre-test and post-test in control class } \\
& s_{1}{ }^{2}=\text { variance of pre-test and post-test in experimental class } \\
& s_{2}{ }^{2}=\text { variance of pre-test and post-test in control class } \\
& n_{1}=\text { total sample in experimental class } \\
& n_{2}=\text { total sample in control class }
\end{aligned}
$$

Based on the result of the calculation, the mean score of writing skill in experimental class was 65.9, the mean score of writing skill in control class was 58.8. The score of $\mathrm{t}$ obtained was 2.97, while the score of t-table was 2.002 with the level of significance of $5 \%$ (0.05) and degree of freedom (df) from $\left(\mathrm{n}_{1}+\mathrm{n}_{2}-2\right)=(30+30-2)=58$. It showed that the score of t-obtained (2.97) was higher than the score of t-table (2.002). Therefore, alternative hypothesis $\left(H_{a}\right)$ was accepted which stated that there was a significant effect of mean score 
between experimental class and control class. In conclusion, the experimental class was given the treatment by using "Save The Last Word For Me" method gave significant effect toward students' writing skill in class VIII-6.

\section{DISCUSSION}

Based on the result in the previous chapter, the mean score of writing skill in experimental class was 65.9, the mean score of writing skill in control class was 58.8. The score of t-obtained was 2.97, while the score of t-table was 2.002 with the level of significance of $5 \%(0.05)$ and degree of freedom (df) from $\left(n_{1}+n_{2}-2\right)=(30+30-2)=58$. It showed that the score of t-obtained (2.97) was higher than the score of t-table (2.002).

Therefore, alternative hypothesis $\left(H_{a}\right)$ was accepted which stated that there was a significant effect of mean score between experimental class and control class. In conclusion, the experimental class was given the treatment by using "Save The Last Word For Me" method gave significant effect toward students' writing skill in class VIII-6. The teacher can use this study be an alternative method and new ideas in teaching writing recount text.

\section{REFERENCES}

Brunner, Judy Tilton. (2011). I don't get It! Helping students understand what they read. United States of America: Rowman \& Littlefield Education.

Irawati, Tatik. (2013). Being an excellent writer with an excellent. Malang, Jatim: Madani Press.

Knoch, Ute. (2009). Diagnostic writing assessment. Internationaler Verlag der Wissenschaften: Peter Lang.

Patel, M.F and Jain, Praveen M. (2008). English language teaching: Methods, tools and techniques. Vaishali Nagar, Jaipur: Sunrise Publishers \& Distributors.

Sugiyono. (2012). Metode penelitian kuantitatif, kualitatif dan R\&D. Bandung: Alfabeta.

Veit, Richard, et al. (2014). Writing, reading and research. University of North Carolina Wilmington: Monica Eckman. 